\title{
Akses Pendidikan bagi Pribumi pada Periode Etis (1901-1930)
}

\author{
Muhammad Fakhriansyah, Intan Ranti Permatasari Patoni \\ Program Studi Pendidikan Sejarah, Universitas Negeri Jakarta \\ Email: fakhriansyah.sejarah@gmail.com
}

\begin{abstract}
This article examines the dynamics of the indigenous people of the Dutch East Indies' access to education during the Dutch Etichal Policy period. Considering that, the Netherlands was the longest-running country exploiting the Indies, the country was obliged to bear the burden of reciprocation on their colony. The burden of reciprocity was realised through an Ethical Policy that has three programs. They are irrigation, transmigration, and education. Of the three, Education was the program that had major impacts on the Indonesian national movement. This research used historical method. The result of this research showed us that although education had succeeded in undermining the Dutch colonial domination, the education during the Dutch Etichal Policy period was not fully given as a whole by the colonial government. Instead, it was very limited. The Dutch colonial policies, especially the one concerning education were driven by their interest of economic benefits for themselves over the improvement of the indigenous people of the Dutch East Indies' welfare.
\end{abstract}

\section{Keywords: Educational Access, Indigeneous People, Ethcical Policy}

Abstrak: Artikel ini membahas mengenai dinamika akses pendidikan bagi pribumi saat berlangsungya Politik Etis. Seperti yang diketahui, Belanda sebagai negara yang terlama mengeksploitasi Hindia Belanda membuat negara tersebut menanggung beban balas budi terhadap koloninya. Beban balas budi tersebut terwujud melalui program Politik Etis yang memiliki tiga program, yakni irigasi, transmigrasi, dan edukasi. Dari ketiga itu, pendidikan merupakan salah satu program Politik Etis dan salah satu program yang memiliki dampak besar bagi pergerakan nasional. Penelitian ini menggunakan metode historis dengan analisis studi kepustakaan. Hasil penelitian menunjukan meskipun pendidikan berhasil meruntuhkan dominasi kolonial, pendidikan saat periode Etis pun tidak serta merta langsung diberikan begitu saja oleh pemerintah kolonial meskipun tujuan Politik Etis adalah balas budi, pemberian pendidikan diberikan secara serba terbatas. Kebijakan-kebijakan pemerintah kolonial, khususnya di bidang pendidikan didorong oleh kepentingan keuntungan ekonomi bagi mereka sendiri alih-alih oleh motif untuk meningkatkan kesejahteraan rakyat setempat.

Kata Kunci: Akses Pendidikan, Pribumi, Politik Etis 


\section{PENDAHULUAN}

Sebagai bagian dari amanat konstitusi, pendidikan merupakan sarana utama dalam pembentukan pola pikir manusia dalam hal untuk peningkatan peradaban dan elevasi manusia. Pendidikan merupakan proses edukatif yang dilakukan secara terus menerus sejak kelahiran hingga kematian (Seeley, 2015:11). Bicara mengenai pendidikan pasti sangatlah rumit dan kompleks, komponen-komponen pendidikan seperti tenaga pendidik, sekolah, lingkungan, dan lain-lain saling terkait membentuk jaringan yang disebut sebagai sistem pendidikan. Sistem pendidikan yang ada pada masa kini merupakan sistem yang lahir melalui proses sejarah yang panjang dan rumit. Sistem pendidikan lahir melalui proses perencanaan dan pelaksanaan yang dipengaruhi oleh kondisi politik, sosial, dan ekonomi, baik dari dalam negeri maupun luar negeri.

Di Indonesia, pendidikan tentu berkembang akibat interaksi dengan negara-negara luar yang datang ke tanah air, salah satunya adalah Belanda, Negara yang berhasil menancapkan pengaruh paling besar terhadap kehidupan masyarakat Indonesia-yang pada masa itu bernama Hindia Belanda. Berawal dari ranah ekonomi (baca: perdagangan), lambat laun Belanda semakin menyadari bahwa Indonesia memiliki potensi yang luar biasa yang pada akhirnya kekuasaan Belanda merambah ranah politis, yaitu dengan mendirikan pemerintahan dan menguras kekayaan demi keuntungan yang besar. Masuknya Belanda ke ranah politis ini kemudian yang berdampak pada banyak hal, termasuk sektor pendidikan. Pemerintah Belanda mulai menjajah Indonesia pada 1619 M, yaitu ketika Jan Pieter Zoon 
Coen menduduki Batavia. Secara umum, penjajahan Belanda ini dapat dibagi ke dalam 2 (dua) periode: masa VOC (Vereenigde Oost indische Compagnie) dan masa pemerintah Hindia Belanda (Nederlands Indie).

Dalam perkembangannya, perkembangan pendidikan sudah dimulai dari masa VOC, yakni dengan didirikannya sekolah untuk melenyapkan agama Katolik dengan menyebarkan agama Protestan (Nasution, 1983:4). Di saat yang bersamaan, terdapat masyarakat yang sudah terdidik dengan pendidikan Islam yang didapat di pesantren atau di langgar (Lambart, 1968: 2). Selepas itu, pendidikan di Nusantara memulai tahapan baru yang lebih progresif ketika memasuki awal abad ke-20, yakni dengan dimulainya zaman Etis dengan semboyannya adalah kemajuan. Kemunculan artikel Een Eereschuld (Utang Kehormatan) yang dimuat dalam majalah De Gids tahun 1899 dan ditulis C. Th van Deventer, telah mendorong lahirnya Politik Etis atau Politik Balas Budi yang secara resmi dicanangkan oleh Ratu Belanda tahun 1901 (Leirissa, 1985: 21-23). Hal ini didasari bahwa pemerintah Belanda mempunyai utang budi dan tanggung jawab moral untuk menyejahterakan masyarakat pribumi. Politik Etis mempunyai tiga program, antara lain mengenai irigasi, transmigrasi, dan pendidikan. Shiraishi (1997: 37) menuturkan bahwa perluasan pendidikan gaya Barat adalah tanda resmi dari Politik Etis. Meskipun pendidikan ini hanya memproduksi jenis tenaga kerja yang diperlukan oleh negara, akan tetapi di sisi lain pendidikan ini penting untuk mengangkat derajat masyarakat pribumi.

Walaupun pendidikan berujung menjadi alat untuk melawan dominasi kolonial dan dapat dengan jelas terlihat bahwa pendidikan-yang 
diberikan pemerintah kolonial-dapat menjadi senjata untuk memberantas kolonialisme di Nusantara. Akan tetapi, terdapat suatu ambivalensi antara Politik Etis dan pendidikan sebagai salah satu programnya. Tulisan ini secara umum membahas mengenai dinamika praktik pendidikan saat berlangsungnya Politik Etis dan bagaimana akses pendidikan bagi pribumi saat periode etis. Politik Etis yang mempunyai tujuan sebagai balas budiatas penderitaan yang dilakukan Belanda-apakah dilakukan tulus dan terbuka bagi pribumi seluas-luasnya? Mengingat apabila mengacu pada tujuan dari Politik Etis, seharusnya pendidikan yang dilakukan dilaksanakan secara terbuka dan tanpa adanya pembatasan. Penulis membatasi cakupan temporal dari 1901, sebagai awal mula dicetuskanya Politik Etis dan sampai tahun 1930, karena pada tahun tersebut sudah muncul sistem pendidikan yang memungkinkan anak-anak Indonesia menempuh pendidikan dari yang terendah hingga tertinggi walaupun terdapat berbagai rintangan dan tantangan yang menghalangi langkah anak Indonesia dalam menempuh pendidikan dan pada tahun tersebut secara statistik jumlah anak pribumi yang bersekolah cukup banyak.

\section{METODE}

Metode penelitian adalah langkah ilmiah yang dilakukan untuk mendapatkan data dengan tujuan tertentu. Adapun metode dalam penelitian historis dengan analisis studi kepustakaan. Metode sejarah adalah menguji dan menganalisa secara kritis rekaman dan peninggalan masa lampau

berdasarkan data yang diperoleh dengan menempuh historiografi 
(Gottschalk, 1986: 32). Terdapat empat langkah penelitian sejarah, yaitu: 1) heuristik; 2) kritik; 3) interpretasi; dan 4) historiografi.

Pada tahap heuristik atau pengumpulan data, peneliti melakukan pencarian sumber yang berkaitan dengan objek yang diteliti. Penelurusan sumber dilakukan dengan studi literatur yang diperoleh melalui studi pustaka dari buku, jurnal penelitian, disertasi, skripsi dan internet. Tahap selanjutnya yaitu tahap kritik intern dan ekstern dilakukan dengan membuat perbandingan dari beberapa sumber dan membandingkannya dengan faktafakta yang ada sebelumnya. Selepas itu terdapat tahap interpretasi atau penafsiran atas sumber yang didapat. Peneliti berupaya membandingkan atau komparasi antar berbagai sumber agar tidak terjadi kesalahan interpretasi. Tahap terakhir ialah historiografi, yakni penulisan yang disusun secara kronologis.

\section{HASIL}

Seperti yang dijelaskan di muka, pendidikan merupakan tanda dari semangat Politik Etis. Pada dasarnya semangat Etis adalah perasaan keadilan. Cita-cita kemanusiaan merupakan sasaran utama dari Politik Etis. Meskipun cita-cita kemanusiaan merupakan sasaran utama dari Politik Etis, pemberian pendidikan kepada pribumi tidak diberikan begitu saja meskipun pendidikan ini merupakan produk dari Politik Etis. Akses warga pribumi kebanyakan atas pendidikan modern ketika itu sangat terbatas. Pendidikan kolonial memang tidak pernah secara sengaja dimaksudkan untuk meningkatkan kesejahteraan penduduk pribumi di wilayah koloni (Boone, 1986: 87-92 dalam Suwignyo, 2019: 2). Bisa dibilang, penguasa kolonial tidak 
mungkin sepenuhnya menerapkan kebijakan yang mengeluarkan pengeluaran besar, seperti pendirian sekolah, jalan raya, jembatan, dan gedung publik. Di sisi lain, kebijakan-kebijakan pemerintah kolonial, khususnya di bidang pendidikan didorong oleh kepentingan keuntungan ekonomi bagi mereka sendiri alih-alih oleh motif untuk meningkatkan keberadaban rakyat setempat (Furnivall, 1939: 365). Hal ini terbukti di Hindia Belanda, bahwa motif pendidikan Politik Etis adalah untuk mendapatkan tenaga kerja terdidik dan murah untuk bekerja untuk perkebunan Belanda dan pegawai kantoran. Telah umum diketahui, sekolah dikelompokan menurut ras dan level mutu yang disaring berdasarkan ras dan sosial yang mereka miliki, yang terbagi menjadi sekolah untuk ras Eropa, Arab, India, dan Cina dan ras pribumi (Suwignyo, 2019: 113).

Gayung bersambut, kebijakan Politik Etis ini menyebabkan semakin banyaknya pendirian sekolah di Hinda Belanda. Sebelum Politik Etis tepatnya pada tahun 1892, sudah terdapat pendirian sekolah untuk pribumi-yang sedikit lebih serius-oleh W.P Groenevelt, Direktur Pengajaran Agama dan Industri. (Nasution, 1983: 37). Sekolah tersebut adalah sekolah kelas satu dan sekolah kelas dua. Sekolah kelas satu pada dasarnya dibuka untuk anak-anak kaum bangsawan dengan lama sekitar 5 tahun dan kebanyakan sekolah kelas satu terdapat di Pulau Jawa. Kurikulum sekolah ini, seperti kurikulum sekolah sebelum tahun 1892-yang hanya bersifat teknis, yaitu membaca, menulis, dan berhitung-dan pada tahun 1907 dimasukan Bahasa Belanda sebagai mata pelajaran. Hingga pada tahun 
1912, sekolah ini di ubah menjadi HIS (Hollands Inlandse School, sekolah khusus pribumi) (Nasution, 1983: 50-52)

Tabel 1. Jumlah Sekolah Kelas Satu (ibid, 52)

\begin{tabular}{ccc}
\hline Tahun & Jawa & Luar Jawa \\
\hline 1899 & 27 & - \\
1904 & 47 & - \\
1907 & 50 & - \\
1909 & 60 & - \\
1910 & 67 & 1 \\
1911 & 73 & 4 \\
1912 & 77 & 9 \\
1914 & 83 & 12 \\
\hline
\end{tabular}

Berbeda dengan sekolah kelas satu, sekolah kelas dua timbul karena pemerintah Belanda tidak mampu secara pendanaan untuk menyajikan pendidikan yang sama bagi seluruh anak Indonesia. Setelah dibentuk, kurikulum sekolah kelas dua dibuat agar tetap lebih rendah daripada sekolah kelas satu, yaitu kurikulum yang dirancang untuk sekadar menambah pengetahuan teknis pada anak Indonesia berupa membaca, menulis, dan berhitung dan diberikan bahasa melayu dan bahasa daerah sebagai komunikasi pembelajaran (Gouda, 2007: 142). Pendirian dua sekolah ini membuat jurang yang lebar antara penyelenggaraan pendidikan untuk kaum bangsawan dan kaum pribumi biasa yang berbeda jauh, baik dari segi kurikulum, fasilitas, guru dan media pendidikan. Hal tersebut dilakukan Belanda, karena mereka menganggap pendidikan digunakan untuk mempertahanan perbedaan sosial dan bukan untuk mobilitas sosial. 
Tabel 2. Jumlah Sekolah dan Murid di Sekolah Kelas Satu dan Sekolah Kelas Dua di Jawa dan Sumatera. 1900-1920 (Suwignyo, 2019: 218)

\begin{tabular}{ccccc}
\hline \multirow{2}{*}{ Tahun } & \multicolumn{2}{c}{ Sekolah } & \multicolumn{2}{c}{ Murid } \\
\cline { 2 - 5 } & Jawa & Sumatera & Jawa & Sumatera \\
\hline 1900 & 238 & 82 & 43617 & 12427 \\
1901 & 254 & 86 & 47911 & 12692 \\
1902 & 265 & 95 & 50734 & 13685 \\
1903 & 285 & 100 & 54951 & 14838 \\
1904 & 301 & 109 & 64064 & - \\
1905 & 313 & - & 71256 & - \\
1910 & 613 & 142 & 126550 & 26125 \\
\hline
\end{tabular}

Selain dua sekolah tersebut, menurut Suwignyo (2012: 63) pada tahun 1907 sekolah desa pertama kali didirikan di Jawa. Sekolah ini didirikan karena pemerintah pusat tidak sanggup untuk mendanai pendirian sekolah untuk pribumi. Sistem sekolah desa atau volkschool, yang pendiriannya bergantung pada kemampuan masyarakat setempat dan diselesaikan dalam waktu tiga tahun-yang diajarkan hanya sekadar membaca, menulis, dan berhitung-murid-murid yang terpilih dapat melanjutkan pendidikannya ke sekolah sambungan atau vervolgschool untuk masa dua tahun. Murid sekolah desa dan sambungan tersebut juga dimungkinkan untuk melanjutkan pelajarannya. Beberapa murid terpilih dari sekolah sambungan diberi kesempatan untuk mengikuti ujian seleksi masuk sekolah normal, sekolah guru untuk sekolah desa, atau sekolah tukang. Pada tahun 1924, murid ini diberi kesempatan melanjutkan studinya ke sekolah bercorak belanda melalui suatu sekolah peralihan yang disebut sekolah schakel.

Setelah pendirian sekolah desa dan bahkan sebelum akhir dekade pertama abad ke-20, di Jawa sudah memiliki tiga jenis sekolah dasar negeri untuk tiga kategori sosial anak yang berbeda. Sekolah Kelas Satu untuk 
kalangan elit, sekolah Kelas Dua untuk kalangan menengah dan bawah, dan sekolah dessa untuk kalangan masyarakat umum pedesaan.

\section{Beberapa Jenis Sekolah saat Periode Etis}

Melalui Politik Etis pribumi sudah mulai bersentuhan dengan pendidikan. Pendidikan yang diperkenalkan oleh pemerintah, tentu saja pendidikan ala barat yang berbeda dengan adat istiadat masyarakat pribumi. Oleh karena itu, pendidikan ala barat disesuaikan dengan budaya masyarakat, misalkan pemakaian bahasa daerah seperti bahasa Sunda dan bahasa Jawa tidak dengan bahasa Belanda (Ricklefs, 2005: 328). Semua pendukung Politik Etis setuju atas peningkatan pendidikan bagi warga pribumi, tetapi ada dua aliran pemikiran yang berbeda mengenai jenis pendidikan dan untuk siapa pendidikan (ibid: 329). Pertama, pemikiran Snouck Hurgronje dan Direktur Pendidikan, J.H. Abendanon, mereka menginginkan pendidikan yang lebih bergaya Eropa dan memakai bahasa Belanda sebagai pengantar bagi kaum elit Indonesia yang dipengaruhi barat. Dengan harapan akan membentuk suatu kerjasama antara pribumi dengan orang Eropa yang akan mempermudah relasi keduanya. Kedua, pemikiran Idenburg dan Gubernur Jenderal van Heutz yang mendukung pendidikan yang lebih mendasar dan menggunakan bahasa daerah sebagai bahasa pengantar bagi golongan bawah. Pendekatan elitis Hurgronje dan Abendanon diharapkan menghasilkan pimpinan bagi zaman penjajahan baru. Sedangkan, pendekatan merakyat diharapkan menghasilkan sumbangan secara langsung bagi peningkatan kesejahteraan. 
Akan tetapi, dalam pandangan Ben Anderson (1983, dalam Shiraishi 1997: 39) pendidikan merupakan sarana bagi pribumi untuk menjadi lebih modern dengan metamorfosis dari pendidikan tradisional dan pendidikan modern. Anderson berpendapat ada dua hal yang mendasari dalam proses metamorfosis tersebut. Pertama, pendidikan adalah kunci bagi mobilitas, tetapi mobilitas yang dimaksud ialah mobilitas di dalam tatanan sosial dengan stratifikasi rasial yang diciptakan dan dipertahankan oleh negara Hindia. Kedua, pengalaman yang mereka peroleh di sekolah dan dalam kehidupan berbeda dengan apa yang didapat dari generasi orang mereka. Dalam artian, mereka mendapat pengalaman yang lebih modern daripada orangtua mereka. Ketika Politik Etis dimulai sudah terdapat beberapa sekolah yang menyelenggarakan praktik pendidikan, seperti sekolah kelas satu, sekolah kelas dua, ELS, HCS, dan HBS. Secara umum penyelengaraan pendidikan yang ditandai dengan pembukaan sekolah bagi pribumi merupakan proses kelanjutan dan respon dari praktik pendidikan yang telah dimulai sebelumnya. Dengan munculnya ide-ide pembaharuan dan menimbulkan dorongan akan pentingnya pendidikan maka, pemerintah kolonial mengizinkan pembukaan beberapa sekolah. Secara umum beberapa jenis sekolah dijelaskan lebih lanjut dalam tabel berikut (Stroomberg, 2018: 89 dan Nasution, 1983: 90-140): 
Tabel 3. Beberapa Sekolah yang berkembang pada zaman periode etis

\begin{tabular}{|c|c|c|c|}
\hline Jenis Sekolah & Nama Sekolah & Lama belajar & Peruntukan \\
\hline \multirow{3}{*}{ Sekolah Rendah } & $\begin{array}{c}\text { ELS } \\
\text { (Europese Lagere School) }\end{array}$ & 7 tahun & $\begin{array}{c}\text { anak-anak keturunan } \\
\text { Eropa , timur asing, } \\
\text { atau pribumi dari } \\
\text { tokoh terkemuka }\end{array}$ \\
\hline & $\begin{array}{c}\text { HCS } \\
\text { (Hollands Chinese school) }\end{array}$ & 7 tahun & $\begin{array}{c}\text { anak-anak keturunan } \\
\text { timur asing, } \\
\text { khususnya } \\
\text { keturunan Cina } \\
\end{array}$ \\
\hline & $\begin{array}{c}\text { HIS } \\
\text { (Hollands Inlandse School) }\end{array}$ & 7 tahun & $\begin{array}{c}\text { Anak-anak khusus } \\
\text { pribumi }\end{array}$ \\
\hline \multirow{3}{*}{$\begin{array}{l}\text { Sekolah Lanjutan } \\
\text { Menegah }\end{array}$} & $\begin{array}{c}\text { MULO } \\
\text { (Meer Uitgebreid Lager } \\
\text { Onderwijs) }\end{array}$ & 3 tahun & $\begin{array}{l}\text { anak pribumi dan } \\
\text { timur asing }\end{array}$ \\
\hline & $\begin{array}{c}\text { HBS } \\
\text { (Hogere Burgerschool) }\end{array}$ & 3 tahun & $\begin{array}{l}\text { golongan Eropa, } \\
\text { bangsawan pribumi }\end{array}$ \\
\hline & $\begin{array}{c}\text { AMS } \\
\text { (Algemene Middelbare School) }\end{array}$ & 3 tahun & $\begin{array}{l}\text { anak pribumi dan } \\
\text { timur asing }\end{array}$ \\
\hline
\end{tabular}

Selain sekolah yang dijelaskan dalam tabel, terdapat sekolah kejuruan dan perguruan tinggi. Sekolah kejuruan didirikan karena kebutuhan yang tinggi akan teknisi mekanik. Umumnya permintaan tersebut datang dari orang Cina yang memerlukan pekerja yang tekun. Dengan permintaan ini, pada tahun 1909 didirikan tiga sekolah besar professional untuk para pribumi meliputi kerajinan kayu, kerajinan besi, tata busana, menggambar secara professional, dan sopir (Stroomberg, 2018: 89). Sekolah kejuruan ini termasuk sekolah keguruan, yaitu kweekschool dan hogere kwekschool (Buchori, 2007: 12). Perkembangan pendidikan tinggi merupakan perjalanan akhir dan menjadi pelengkap dalam alur system pendidikan di Hindia Belanda (Nasution, 1983: 144). Perguruan tinggi di Hindia Belanda yang tidak memandang ras tidak menjadikan sekolah sebagai bagian dari penggolongan 
sosial-muncul pada tahun 1920 dengan dibukanya Technische Hoge School (THS) di Bandung diiiringi dengan pendirian Rechskundige Hoge school di Batavia tahun 1924. Diluar itu, sekolah-sekolah bergaya barat lain seperti OSVIA (Opleiding School Voor Inlandsche Ambtenaren), yang merupakan sekolah untuk mendidik pamong pribumi, STOVIA (School tot Opleiding van Indische Artsen) yang merupakan sekolah kedokteran Jawa, dan NIAS (Nederlansch Indische Artsen School), yang merupakan sekolah kedokteran di Surabaya. Selain itu, salah satu yang perlu dicatat adalah pendirian akademi pemerintahan atau bestuurakademie, yang menerima murid AMS dan berprogram selama tiga tahun.

Suwignyo (2018: 113) mengungkapkan penambahan jumlah sekolah sebagai bagian peluasan akses pendidikan tidak dibarengi penghapusan segregasi dan diskriminasi yang membatas kesempatan warga pribumi. Misalkan saja di ELS, pendirian sekolah ini berawal dari masalah atas ketidakinginan orangtua anak Belanda untuk mencampurkan anaknya dengan anak golongan rendah, karena pada saat itu terdapat sekolah bermutu rendah karena guru yang kurang kompeten dan murid yang berlatar belakang tidak baik (Nasution, 1983: 92). Ketidakinginan tersebut mengharuskan para orang tua mengirimkan anaknya ke Negeri Belanda sehingga didirikanlah ELS pada 1883.

Lebih lanjut mengenai HIS, seperti yang dikatakan Marwati dan Nugroho (2008: 127), HIS dimaksudkan sebagai standenschool, sekolah yang berdasarkan status. Berdasarkan ketentuan pemerintah, ada empat penilaian yang memungkinkan orangtua mengirimkan anaknya ke HIS, yaitu 
keturunan, jabatan, kekayaan, atau pendidikan. Penilaian tersebut dapat diinterpretasikan bahwa di HIS saja masih terdapat penggolongan berdasarkan empat penilaian tadi. Pada umumnya pendidikan digunakan pribumi sebagai sarana untuk mobilitas sosial ke yang lebih baik. Pekerjaan dan pencerahaan pengetahuan gaya barat menjadi daya tarik untuk bisa mendapat "tempat" yang lebih baik.

Pendidikan sebagai media untuk menggapai modernitas bagi pribumi semakin dipersulit dengan dibuatnya kebijakan politik pendidikan (akan di jelaskan lebih lanjut). Permasalahan ini dijumpai pada ELS yang sedianya didirikan untuk memberi pendidikan bagi anak Belanda dan mereka yang disamakan statusnya-bangsawan pribumi. Seperti di lansir tirto.id (22 Juni 2019,https://tirto.id/betapa-susah-orang-pribumi-masuk-sekolah-elite-zamankolonial-ecN7) terdapat kasus ketika pribumi harus berjuang keras menghadapi rintangan dan tantangan untuk bersekolah di ELS. Kasus tersebut dialami oleh Wage Rudolf Supratman yang diterima di kelas tiga ELS Makassar, dan beberapa bulan setelahnya ia dikeluarkan karena ia bukan anak kandung Sersan Willem van Eldik (Saudara iparnya yang berdarah Belanda).

Akan tetapi, penerimaan anak-anak pribumi merupakan masalah yang rumit dan panjang akibat dari dinamika situasi politik yang berubah-ubah. Kesulitan akses tersebut nyatanya tidak menolak keseluruhan anak pribumi, tetapi diseleksi berdasarkan berapa banyak dan siapa anak Indonesia yang diterima (darimana mereka berasal). Sesuai dengan kebijakan politik pendidikan saat itu, penerimaan anak pribumi dibolehkan asalkan jumlah 
muridnya kurang dari jumlah anak Belanda. Christina Maria Lambert dalam disertasinya Colonial Education Policy and Practice in Indonesia: 1900-1942 (1968:130), mengungkapkan bahwa status social dan keuangan orang tua menjadi dua faktor yang menentukan kelayakan untuk masuk ke dalam HIS, meskipun HIS itu sendiri sudah diperuntukan untuk pribumi.

Kesempatan belajar bagi anak pribumi tidak sebaik anak bangsa lain. Pendidikan barat yang relatif mahal bagi orang pribumi membuat para orang tua harus merogoh kocek yang dalam untuk pendidikan. Belum lagi sekolah Belanda pada umumnya terdapat di kota besar sehingga menyebabkan perlunya dikerluakan uang untuk transportasi dan penginapan.

Ricklefs (2005: 335-336) secara detail memaparkan angka statistik mengenai kesempatan belajar bagi pribumi yang dijabarkan setelah ini. Kesempatan belajar di MULO pun menjadi sorotan lantaran cukup tinggi angka partisipasi pribumi yang bersekolah di MULO. Walaupun pada mulanya murid MULO berasal dari ELS dan HIS, persentase murid anak pribumi meningkat dari 4.8\% (1912) menjadi 24\% (1914). Pembentukan MULO sendiri pada dasarnya untuk menampung murid Pribumi yang tidak dapat melanjutkan studinya ke ELS. Meskipun akses pendidikan bagi pribumi sangat dinamis, angka partisipasi pendidikan meningkat. Pada awal 1900 sudah mulai ada 265.940 anak pribumi yang bersekolah-baik swasta maupun sekolah pemerintah. Pada tahun 1930-1931, 1,7 juta orang memasuki sekolah barat akan tetapi jumlah tersebut termasuk sedikit dibanding betapa banyaknya penduduk saat itu dan sekitar 1,66 juta menuntut ilmu di sekolah dasar. Jumlah ini berarti 2.8\% dari keseluruhan jumlah penduduk atau $8 \%$ 
dari kelompok penduduk antara anak yang belum dapat berjalan dan orang dewasa. Secara angka, jumlah orang pribumi yang bersekolah di sistem sekolah eropa (HIS, MULO, AMS) adalah 84.609 orang; $0.14 \%$ dari keseluruhan jumlah penduduk. Dalam lingkup perguruan tinggi sangat sedikit mahasiswa pribumi dalam tiga lembaga pendidikan tinggi yang ada (THS, RHS, STOVIA) hanya terdapat 178 orang pribumi; 0,0003\% (3/1.000.000) dari jumlah penduduk. Namun, dari sedikit orang yang mengenyam bangku pendidikan tinggi, terdapat orang pertama yang berhasil meraih gelar doctor di Universitas Leiden, yakni Hoesein Djajadiningrat, seorang yang berasal dari salah satu keluarga terkemuka di Jawa Barat.

Keberadaan pribumi dalam perguruan tinggi pada saat itu cukup menarik perhatian yang dapat dilihat pada table di bawah (Marwati dan Djonoed, 2008: 118).

Tabel 4. Keberadaan pribumi dalam perguruan tinggi

\begin{tabular}{cccc}
\hline Tahun Ajaran & Pribumi & Eropa & Cina \\
\hline $1920 / 1921$ & 2 orang & 29 orang & 4 orang \\
$1926 / 1927$ & 30 orang & 28 orang & Tidak ada data \\
$1928 / 1929$ & 44 orang & 55 orang & Tidak ada data \\
\hline
\end{tabular}

Berdasarkan tabel di atas, dalam kurun tahun ajaran 1920/1921 hingga 1926/1927 terdapat kenaikna yang signifikan. Kenaikan tersebut ditengarai disebabkan oleh semakin tingginya minat masyarakat untuk ikut dalam arus pencerahan gaya barat dan semakin digencar-gencarkannya pendidikan oleh organisasi pergerakan. Dari total keseluruhan, sejak dibukanya perguruan tinggi, ialah sebanyak 3.242 orang, di antaranya 1.489 orang dari golongan 
priibumi (45 persen), dari golongan eropa sebanyak 1.012 orang (32 persen) dan dari golongan cina sebanyak 741 orang (23 persen).

\section{PEMBAHASAN}

Pemerintah kolonial belanda yang berkeinginan untuk mendikotomikan pendidikan untuk pribumi dan golongan atas sudah jelas terlihat ketika Groenvelt membuat kebijakan untuk memisahkan hal itu. Dengan asumsinya, bahwa ia mendapati suatu kasus ketika pribumi yang ingin menjadi pegawai mendapat proporsi pendidikan berupa materi yang lebih sedikit dibanding dengan pribumi yang hanya ingin bersekolah tanpa adanya keingingan menjadi pegawai. Dengan melihat seperti itu, ia pun mendirikan sekolah kelas satu dan sekolah kelas dua yang menjadi simbol bahwa terdapat garis pemisah-yang beriring jalannya waktu semakin besar-antara keduanya. Ketika sekolah kelas satu aksesnya "dipersulit" dengan beragam syaratnya, sekolah kelas dua pun memiliki dinamika akses yang serupa. Sekolah kelas dua yang notabenenenya ditunjukan untuk anakanak pribumi nyatanya "dipermainkan" oleh pemerintah kolonial. Sekolah ini pun nyatanya mempunyai implikasi yang besar kepada muridnya terhadap kegundahan diantara modernitas dan tradisi tradisional. Lebih lanjut menurut Van Niel (1984: 99), bahwa sekolah kelas dua tidak hanya mengajarkan pendidikan yang lebih lanjut, tetapi juga memisahkan pelajarpelajar dari lingkungan tradisi pola-pola Jawa. Dengan keadaan seperti ini, masuklah individualisme dalam kehidupan yang bertentangan dengan tradisi biasanya. 
Dalam konteks sosial budaya, sistem pendidikan saat itu tidak bisa lepas seutuhnya dari bayang-bayang kolonial. Suwignyo (2012: 70-71) menuturkan bahwa pendidikan untuk pribumi harus selaras dengan kondisi sosial budaya orang Eropa dengan tidak memperhatikan kondisi sosial budaya masyarakat setempat. Hal ini terjadi pada perubahan sekolah kelas satu menjadi HIS pada tahun 1914 yang mencerminkan perubahan misi yang harus diikat oleh pendidikan untuk penduduk Indonesia yang tidak lagi diarahkan pada hubungan antara sekolah dan berbagai bidang unik masyarakat lokal, tetapi antara dua entitas yang berbeda secara budaya dalam dua masyarakat-Timur dan Barat. Oleh karenanya, sekolah difungsikan sebagai penghubung antara dua entitas tersebut.

Perhatian pendidikan kepada pribumi dilanjutkan dengan pendirian sekolah desa-setelah pembentukan sekolah kelas satu dan sekolah kelas dua. Sekolah ini nyatanya mendapat perhatian "lebih" dari pemerintah kolonial. Sekolah yang didirikan dengan tujuan untuk mencerahkan masyarakat akan pentingnya pengetahuan ternyata mendapat bantuan dana (baca:subsidi) untuk operasional sekolahnya. Marwati dan Nugroho (2008: 114) menuliskan bahwa pendirian sekolah ini turut didasari atas meluasnya pengaruh pemerintah dalam kehidupan ekonomi dan administratif. Korelasi antara pendirian sekolah dengan meluasnya pengaruh pemerintah dijelaskan pula oleh Van Niel (1984: 75). Menurutnya, perluasan pengaruh pemerintah di segala lini kehidupan, membuat kebutuhan birokrasi Hindia Belandaa yang bependidikan Barat bertambah besar. Bila sebelumnya kedudukankedudukan tinggi dalam hierarki kepegawaian didasarkan atas keturunan, 
politik kolonial yang baru membuat pendidikan sebagai suplemen pada asal keturunan dan dalam ukuran waktu dan keadaan tertentu pendidikan dijadikan sebagai ukuran utama.

Dalam menyusun sistem pendidikan dan pengajaran, pemerintah kolonial tidak hanya menghadapi masalah pengajaran umum dan kejuruan, tetapi juga masalah pendidikan elitis dan kerakyatan. Pendidikan elitis pada hakikatnya merupakan konsekuensi logis dari suatu politik yang berpengangan pada prinsip dualisme. Sistem pendidikan yang dualistis membuat garis pemisah tajam antara sekolah Eropa dan sekolah pribumi. Lebih lanjut, (Ricklefs, 2005: 329) gagasan pendidikan elitis untuk rakyat dibentuk dengan tujuan agar rakyat dapat bekerja sama dan tahu terima kasih kepada pemerintah kolonial. Sedangkan, gagasan pendidikan kerakyatan murni dengan tujuan untuk mensejahterakan masyarakat. Supardan (2008: 99) mengatakan bahwa pendidikan elitis yang diharapkan menghasilkan pemimpin di zaman pencerahan. Selain itu mereka berusaha keras untuk memperbanyak jumlah pendirian sekolah-sekolah baru.

Setelah dibentuknya beberapa sekolah oleh pemerintah colonial, nyatanya masyarakat pribumi tidak serta merta ikut dalam arus pencerahan pendidikan gaya barat. Pemerintah colonial pun dinilai setengah hati dalam memberikan pendidikan kepada kaum pribumi. Nasution (1983: 20-33) menggambarkan ciri-ciri umum mengenai politik pendidikan Belanda yang dapat menggambarkan bagaimana sulitnya akses pendidikan bagi pribumi pada saat Periode Etis, mengingat pendidikan merupakan salah satu program dari Politik Etis. Ibarat dua sisi koin mata uang, kebijakan politik 
dan kebijakan pendidikan sangat erat hubungannya. Hubungan antara keduanya tersebut didasari karena Belanda sangat berkuasa sehingga mengabaikan substansi dari nilai Etis. Dari sikap tersebut lahirnya beberapa ciri umum, antara lain :

Pertama, prinsip dualisme. Prinsip ini ditandai dengan menekankan perbedaan yang tajam antara pendidikan Belanda dan pendidikan pribumi, seperti misalnya adanya sekolah untuk anak Belanda (western) dan anak pribumi (inladns onderwijs), sekolah untuk orang yang berada dan untuk yang tidak berada, sekolah yang memberi kesempatan melanjutkan pelajaran dan sekolah yang tidak memberi kesempatan itu. Pendidikan digunakan untuk mempertahanan perbedaan sosial dan bukan untuk mobilitas sosial. Prinsip ini membuat garis pemisah tajam antara dua subsistem dalam sekolah (Kartodirjo, 1987: 356)

Kedua, prinsip gradualisme. Prinsip ini mengusahakan pendidikan rendah yang sesederhana mungkin bagi anak Indonesia dan memperlambat lahirnya sekolah yang setara dengan ELS. Pemerintah kolonial dinilai lamban dan tidak niat dalam memajukan pendidikan sehingga pendidikan di Hindia Belanda bisa dikatakan lumpuh total. Ketakutan akan pemberontakan yang dilakukan pribumi, biaya pendidikan yang mahal, ketidakmauan Belanda mengurusi pendidikan karena takut menganggu adat istiadat, dan adanya pandangan bahwa pemberian pendidikan tidak menjamin akan mendapatkan pekerjaan membuat gradualisme semakin besar

Ketiga, adanya kontrol sentral yang kuat. Kontrol sentral yang ketat menciptakan birokrasi yang ketat yang hanya memungkinkan perubahan 
kurikulum dengan persetujuan para pembesar di Indoneia maupun di negeri Belanda. Hal ini juga mengakibatkan lambannya perubahan pendidikan di bawah pemerintahan Belanda.

Keempat, prinsip konkordansi. Prinsip ini mengharuskan semua sekolah berorientasi Barat mengikuti model sekolah di Negeri Belanda dan menghalangi penyeseuaian dengan keadaan di Indonesia sehingga menjadikan sekolah sebagai agen kebudayaan barat. Tentu hal ini sangat kontradikif di mana pendidikan barat ditakutkan akan menjauhkan pribumi dari nilai-nilai budaya lokal. Akan tetapi di sisi lain, pengetahuan barat dapat memperluas cakrawala orang Indoneia dan pendidikan barat menjadi instrumen penentang kolonialisme Belanda.

Kelima, tidak adanya perencanaan pendidikan sistematis. Perencanaan yang tidak matang terhadap pendidikan membuat pemerintah berulang kali menguji coba berbagai macam sekolah sesuai perkembangan zaman. Perkembangan zaman yang dimaksud adalah perkembangan perihal kompromi mengenai akses pendidikan minimal bagi pribumi sebagai respon atas tuntuan dari pihak pribumi untuk memperoleh akses pendidikan setara dengan orang Belanda.

Keenam, keterbatasan tujuan setelah lulus sekolah. Keterbatasan tujuan maksudnya pelaksanaan pendidikan hanya sebagai penyedia pegawai pemerinytah yang terdidik. Sekolah pertama untuk anak-anak Indonesia di dirikan dengan tujuan untuk mendidik anak-anak aristokrasi Jawa menjadi pegawai perkebunan pemerintah. Perluasan pendidikan sebagian besar 
ditentukan oleh kebutuhan pegawai dan juru tulis yang terus meningkat (Imsawati, Handayani, Sumardi, 2017: 284)

Dalam konteks kolonial, Suwignyo (2018: 113) menuturkan bahwa tujuan pemerintah kolonial menyediakan pendidikan bagi warga pribumi belum beranjak dari desain sebelum Politik Etis, yakni dihasilkannya pegawai terampil yang mau digaji rendah. Oleh karenanya, seperti yang sudah disinggung di muka, pendidikan kolonial tidak pernah sengaja dimaksudnya untuk meningkatkan kesehjateraan penduduk pribumi di wilayah koloni. Dengan kata lain, melalui pendidikan pemerintah kolonial hanya "memanfaatkan" pribumi untuk menghasilkan tenaga kerja yang kompeten namun bergaji rendah. Pada umumnya pendidikan digunakan pribumi sebagai sarana untuk mobilitas sosial ke yang lebih baik. Pekerjaan dan pencerahaan pengetahuan gaya barat menjadi daya tarik untuk bisa mendapat "tempat" yang lebih baik. Akan tetapi berpijak pada pandangan Ben Anderson di atas, identitas pribumi atau "bumiputera" tetaplah melekat sebagai identitas asli. Apabila kita mengalami kenaikan stratifikasi, identitas kita tetaplah "bumiputera" atau "pribumi" meskipun telah mengalami modernitas.

Kebijakan pemerintah yang cenderung membatasi pribumi dalam mengenyam pendidikan ini menuai perlawanan dari masyarakat. Kesulitan yang dibuat pemerintah kolonial mendorong masyarakat untuk membentuk sekolah sendiri yang menurut perspektif pemerintah disebut sebagai sekolah liar. Meskipun mereka di cap illegal-dalam wilden scholen ordonantielulusan sekolah liar bisa dikatakan setara dengan lulusan dengan sekolah 
Eropa biasa. Dalam artian, walaupun tradisi pendidikan mereka (lulusan sekolah liar dan sekolah Eropa) berbeda, akan tetapi keduanya menghadapi situasi dan kemungkinan sosial yang hampir sama. Mereka bergerak bersama dalam kemajuan dengan landasan ideologis yang berbeda. Yang satu golongan terpelajar Barat dan yang lain golongan terpelajar berlandaskan agama dan kebudayaan. Misalkan Taman Siswa besutan Ki Hajar Dewantara yang lebih mengutamakan pendidikan berlandaskan kebudayaan jawa dan tertulis di dalam tujuh butir prinsip taman siswa. Persaingan, pergolakan, serta persekutuan yang saling berganti antara kelompok-kelompok terpelajar barat dan agama menjadi sesuatu yang penting dalam dinamika kehidupan pergerakan nasional.

\section{KESIMPULAN}

Sejak dimulainya Politik Etis pada tahun 1901, harapan akan pencerahan terhadap pribumi semakin besar. Program-program Politik Etis ditengarai dapat meningkatkan taraf hidup masyarakat pribumi. Apabila membicarakan pendidikan-sebagai salah satu program Politik Etis, berarti membicarakan dinamika terpenting dalam kehidupan pergerakan dan perkembangan masyarakat kolonial, meskipun pendidikan yang dilakukan

pemerintah tidak terbuka. Proses edukatif zaman tersebut memang dilakukan dan dirancang untuk dipersulit dan memakan waktu yang lama. Walaupun seperti itu, komponen sekolah modern menjadi saluran terwujudnya manusia pribumi yang modern dan kritis. Sekolah bukan saja harus dilihat sebagai alat modernisasi masyarakat dan media mobilitas sosial, tetapi harus dilihat pula bagaimana pendirian sekolah ini mengartikan 
bahwa kebijakan politik pemerintah kolonial pun merambah hingga ke ranah pendidikan. Kebijakan politik tersebut yang didasari "beban" balas budi terhadap Hindia Belanda membuat sekolah yang dibuat dan diperkenalkan pemerintah kolonial serba terbatas.

Terwujudnya poltik balas budi terhadap Hindia Belanda menjadi momentum penting dalam sejarah pergerakan nasional, para pemuda dengan tegas menyatakan dirinya adalah kaum muda dengan semangat baru. Karena itu mereka-melalui pendidikan-berhasil meruntuhkan dominasi politik kolonial yang diibaratkan tembok besar yang menghadang pribumi ketika mereka ingin memperbaiki kehidupannya lewat pendidikan. Walaupun seperti itu, pendidikan mengalami transformasi yang bukan saja menghasilkan pegawai, tetapi menghasilkan manusia nasionalis dan anti kolonial yang bergerak meruntuhkan dominasi kolonial.

\section{DAFTAR PUSTAKA}

[1]. Buchori, Mochtar. 2007. Evolusi Pendidikan di Indonesia: Dari Kweekschool Sampai ke IKIP (1852-1998). Yogyakarta: INSISTPress.

[2]. Furnivall, J.S (1939). Netherlands India: A Study of Plural Economy. Cambridge: Cambridge Press.

[3]. Gouda, Frances. (2007). Dutch Cultures Overseas: Praktik Kolonial di Hindia Belanda, 1900-1942. Jakarta: Serambi. (Edisi asli buku ini adalah dalam bahasa Inggris berjudul Frances Gouda, Dutch Culture Overseas: Colonial Practice in the Netherlands Indies, 1900-1942 [Amsterdam: Amsterdam University Press, 1995]).

[4]. Gootschalk, L. (1969). Mengerti Sejarah. Jakarta: Universitas Indonesia Press. 
[5]. IMSAWATI, Dwi Nur; HANDAYANI, Sri; SUMARDI. (2017) The Intelectual's Constribution In The National Movement Of In Indonesian 1908-1928. JURNAL HISTORICA, 1(2): 277-292

[6]. Kartono, Sartodirjo (1988). Pengantar Sejarah Indonesia Baru: 1500-1900. Jakarta: Gramedia Pustaka Utama

[7]. Kenji, Tsuchiya. (1992). Demokrasi dan Kepemimpinan: Kebangkitan Gerakan Taman Siswa. Jakarta: Balai Pustaka. (Edisi asli buku ini adalah dalam bahasa Inggris berjudul Tsuchiya Kenji. Democracy and Leadership: The Rise of the Taman Siswa Movement in Indonesia [Honolulu: University of Hawai Press, 1988]).

[8]. Leirissa, R.Z. (1985) Sejarah Masyarakat Indonesia 1900-1950: Terwujudnya Suatu gagasan, Jakarta:PB. PGRI.

[9]. Maria, Christina Lambert. (1968). "Colonial Education Policy and Practice in Indonesia: 1900-1942". PhD Dissertation. Australian National University.

[10]. Matanasari, Patrick. (24 Oktober 2016). Citing Internet sources URL https://tirto.id/sekolah-sekolah-di-zaman-belanda-bXbV

[11]. Matanasi, Patrick. (22 Juni 2019). Citing Internet Sources URL https://tirto.id/betapa-susah-orang-pribumi-masuk-sekolah-elite-zamankolonial-ecN7

[12]. Nagazumi, Akira. (1989). Bangkitnya Nasionalisme Indonesia: Budi Utomo 1908-1918. Jakarta: Pustaka Utama

[13]. Nasution. 1983. Sejarah Pendidikan Indonesia. Jakarta: Bumi Aksara.

[14]. Poesponegoro, M.D \& Nugroho Notosusanto. (2008). Sejarah Nasional Indonesia Jilid III. Jakarta: Balai Pustaka.

[15]. Ricklefs, M.C. (2005). Sejarah Indonesia Modern: 1200-2004. Jakarta: Serambi. 
[16]. Seeley, Levi. (2015). Sejarah Pendidikan. Yogyakarta: Indo Literasi. (Edisi asli buku ini adalah dalam bahasa Inggris berjudul Levi Seeley, History of Education [New York: American Book Company, 1899])

[17]. Setiaji, Hilmawan Aris. (2011). “WANITA JAWA DALAM PENDIDIKAN KOLONIAL (Studi Sekolah Van Deventer di Mangkunegaran Surakarta)". Skripsi. Universitas Sebelas Maret.

[18]. Shiraishi, Takashi. 1997. ZAMAN BERGERAK: Radikalisme Rakyat di Jawa, 1921-1926. terj. Hilmar Farid. Jakarta: PT. Pustaka Utama Grafiti . (Edisi asli buku ini adalah dalam bahasa Inggris berjudul Takashi Shiraihi, An Age in Motion: Popular Radicalism in Java, 1912-1926 (New York: Cornell University, 1990])

[19]. Stroomberg, J. (2018). Hindia Belanda 1930. Yogyakarta: IRCiSoD. (Edisi asli buku ini adalah dalam bahasa Inggris berjudul Dr. J. Stroomberg, Handbook of the Netherlands East Indies, 1930 [Buitenzorg: Department of Agriculture, 1930]

[20]. Supardan, Dadang. (2008). "Menyingkap Perkembangan Pendidikan Sejak Masa Kolonial Hingga Sekarang: Perspektif Pendidikan Kritis". Generasi Kampus, 1(2): 96-106.

[21]. Susilo, Agus. (2018). "Politik Etis dan Pengaruhnya Bagi Lahirnya Pergerakan Bangsa Indonesia". Jurnal Historia, 6(2): 403-416.

[22]. Suwignyo, Agus. (2012). "The breach in the dike : regime change and the standardization of public primaryschool teacher training in Indonesia, 1893-1969". PhD Dissertation. Universiteit Leiden.

[23]. Suwignyo, Agus (2019). Pendidikan, Kekuasaan, dan Kolonialisme. Jogjakarta: Quantum Jogja.

[24]. Van Niel, R. (1984). Munculnya Elit Modern Indonesia. Jakarta: Dunia Pustaka Jaya. (Edisi asli buku ini adalah dalam bahasa Inggris berjudul Robert Van Niel, The Emergence of The Modern Indonesian Elite [Den Haag: N.V. Uitgeverij W. van Hoeve, 1960]) 
[25]. Zed, Mestika. (2008). Penelitian Kepustakaan. Jakarta: Obor. 